\title{
TREND OF AMMONIA EMISSIONS FROM LIVESTOCK SECTOR IN LATVIA
}

\author{
Olga Frolova $^{1}$, Juris Priekulis ${ }^{1}$, Laima Berzina ${ }^{1}$, Aivars Aboltins ${ }^{1}$ \\ ${ }^{1}$ Latvia University of Life Sciences and Technologies, Latvia \\ olga.frolova@1lu.lv,juris.priekulis@1lu.lv, laima.berzina@1lu.lv, aivars.aboltins@1lu.lv
}

\begin{abstract}
The article analyses the sources of ammonia $\left(\mathrm{NH}_{3}\right)$ emissions in Latvia and the trends from 2005 to 2018 with the focus on agricultural production. The study is based on the annual Latvia's Informative Inventory Report 1990 - 2018 submitted under the Convention on Long - Range Transboundary Air Pollution Annex I data. It is crucial to decrease $\mathrm{NH}_{3}$ emissions due to their toxic nature to the ecosystems and health of living beings as $\mathrm{NH}_{3}$ not only contributes to acidification of water ecosystems, but also to formation of secondary particles. There is a trend of increase of $\mathrm{NH}_{3}$ emissions from agriculture production in the study period $(+12 \%$ comparing 2018 to 2005) opposed to the need to reach the national goal to decrease $\mathrm{NH}_{3}$ emissions to the reference accounted in 2005 (1\% $\mathrm{NH}_{3}$ reduction). There is decrease of $\mathrm{NH}_{3}$ emissions for about $5 \%$ from agriculture comparing 2018 and 2017 due to rapid decrease of farming animals. The largest increase of $\mathrm{NH}_{3}$ emissions in the latest years in Latvia is observed from the use of inorganic fertilizers $(+57 \%)$, because there is increase of the incorporated nitrogen $(\mathrm{N})$ to soils. The lowest use of inorganic fertilizers was in $1995(11.5 \mathrm{kt} \mathrm{N})$ in the inventory period $1990-2018$. There is decrease of emissions from the whole manure management cycle about 6\% comparing 2018 to 2005 . However, manure management is still the biggest source of $\mathrm{NH}_{3}$ emissions ( $73 \%$ from agricultural $\mathrm{NH}_{3}$ emissions), therefore, with the highest potential to decrease national $\mathrm{NH}_{3}$ emissions as there are plenty of options to limit $\mathrm{NH}_{3}$ from manure in all stages of livestock breeding and manure management (feeding, livestock housing, manure storage and application to soils). To reach the goal of $\mathrm{NH}_{3}$ emissions reduction these all measures need to be accountable by developing a national model for estimation of annual $\mathrm{NH}_{3}$ emissions, which should be based on detailed statistical data about manure management practices.
\end{abstract}

Keywords: ammonia, livestock farming, trend of emission.

\section{Introduction}

Ammonia $\left(\mathrm{NH}_{3}\right)$ is colourless gas with specific odour found in air, water and soil. $\mathrm{NH}_{3}$ and its chemical components are important to metabolism of domestic animals. Animal manure as well as plant residues and organic matter decomposition processes are the source of $\mathrm{NH}_{3}$ to the environment. However, human activities affect the amount of $\mathrm{NH}_{3}$ and its chemical elements and can significantly increase it beyond the desired natural level and lead to negative changes of the aquatic ecosystems by wet and dry deposition and contribute to creation of fine particles [1].

Therefore, our country has a target: to deliver $1 \%$ reduction in $\mathrm{NH}_{3}$ emissions by 2020 , compared to 2005, and a further $1 \%$ by 2030 [2], but for this moment total national $\mathrm{NH}_{3}$ emissions are increased (+6\% comparing 2018 to 2005) [3]. The European Union (EU) total $\mathrm{NH}_{3}$ emissions have increased by $0.4 \%$ from 2016 to 2017, but from 2005 to $2017 \mathrm{NH}_{3}$ emissions decreased by $4 \%$. The biggest contributors of $\mathrm{NH}_{3}$ emissions are Germany, France and Spain. Latvia's share of the total $\mathrm{EU} \mathrm{NH}_{3}$ emissions is $0.4 \%$ in 2017. Agriculture contributed $92 \%$ of the total $\mathrm{EU} \mathrm{NH}_{3}$ emissions in 2017. The highest share of $\mathrm{NH}_{3}$ emissions in the EU is from manure applied to soils [4]. In Latvia, the largest $\mathrm{NH}_{3}$ emissions in the agricultural sector, originate from livestock farming. It has been estimated that the production, storage and use of manure as fertilizer represent approximately $73 \%$ of the total amount of $\mathrm{NH}_{3}$ emissions from agricultural production and $61 \%$ from the total national $\mathrm{NH}_{3}$ emissions, but mineral fertiliser use for $25 \%$ and $21 \%$, respectively [3].

The aim of this article was to assess the main causes of $\mathrm{NH}_{3}$ emissions in the livestock sector and to explore the possible solutions to improve this situation in the near future. Investigation of the key categories and change in time can help identify the possible measures to help reach the nation goal of reduction of $\mathrm{NH}_{3}$ emissions.

\section{Materials and methods}

For the study, the absolute values of $\mathrm{NH}_{3}$ emissions reported in the Latvia's Informative Inventory Annex I [3] were used for the agricultural sector from 2005 to 2018 to analyse the trend. These are the most current available national data at this point. The analysis included the estimated annual total $\mathrm{NH}_{3}$ emission and breakdown for individual sources of emissions. 
To compare $\mathrm{NH}_{3}$ emissions from agriculture in 2005 (reference year) with 2018, equation (1) was used.

$$
\Delta=\frac{\left|A_{1}-A_{2}\right|}{A} \cdot 100
$$

where $\Delta-\mathrm{NH}_{3}$ emissions difference, \%;

$A_{1} ; A_{2}$ - last and first year $\mathrm{NH}_{3}$ emissions compared in the study, $\mathrm{kt}$;

$A-\mathrm{NH}_{3}$ emission in the reference year, kt.

Equation (1) was also used to estimate the difference of emissions for two recent years, because there was a visible decrease of $\mathrm{NH}_{3}$ emissions from 2017 to 2018. To describe the trend of $\mathrm{NH}_{3}$ emissions from 2005 to 2018 , all livestock originated emissions were summarized in the category "livestock farming". It is the total sum of $\mathrm{NH}_{3}$ emissions from all livestock groups in different stages of manure management: housing, storage, grazing and application to soil.

\section{Results and discussion}

In Figure $1 \mathrm{NH}_{3}$ emissions reported in the Latvia's Informative Inventory over the period 20052018 are summarised.

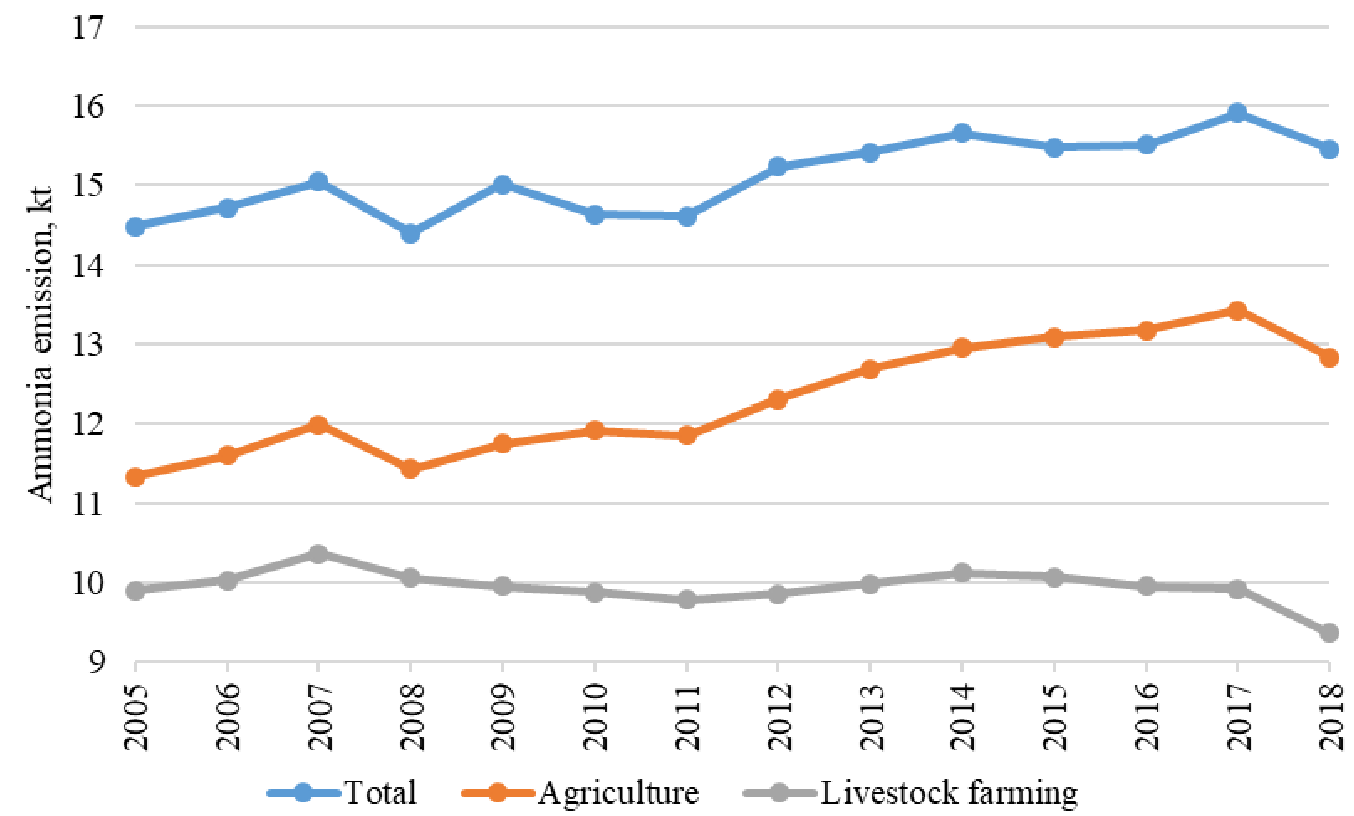

Fig. 1. Latvia's $\mathbf{N H}_{3}$ emissions from 2005 to 2018

Figure 1 shows that $\mathrm{NH}_{3}$ emissions from the agricultural sector increased, but in 2018 there is a drop of emissions by $0.59 \mathrm{kt}$. Decrease in 2018 is directly dependent on fluctuation of the livestock number. For example, the number of dairy cattle decreased by $3.93 \%$ from 2017 to 2018 [3]. Overall, the trend of total $\mathrm{NH}_{3}$ emissions is increasing. Therefore, there is a concern whether it is possible to reach the $\mathrm{NH}_{3}$ emission reduction goals, because the decrease of emissions in 2018 is livestock number driven and could be only one year phenomenon. Livestock manure management $\mathrm{NH}_{3}$ emissions have been relatively stable for the past years (fluctuation was around $10 \mathrm{kt}$ ).

There is increase of $\mathrm{NH}_{3}$ emissions in agriculture by $12 \%$ from 2005 to 2018, but comparing 2018 to 2017, there is decrease by $5 \%$ (Figure 2). Manure managent is the bigest source of $\mathrm{NH}_{3}$ emissions. Manure management in farms (from livestock housing and manure storage) is accountable for $51 \%$ in 2018, but in 2005 they were $65 \%$ from agricultural $\mathrm{NH}_{3}$ emissions. The change of $\mathrm{NH}_{3}$ emissions is from 7.33 to $6.54 \mathrm{kt}$ (about $-11 \%$ ). It is due to fluctuation of the number of livestock. The number of cattle changed from 385 thousand in 2005 to 406 thousand in 2017, and 395 thousand in 2018. The number of swine changed from 428 thousand in 2005 to 321 thousand in 2017, and 305 thousand in 2018 [5]. 


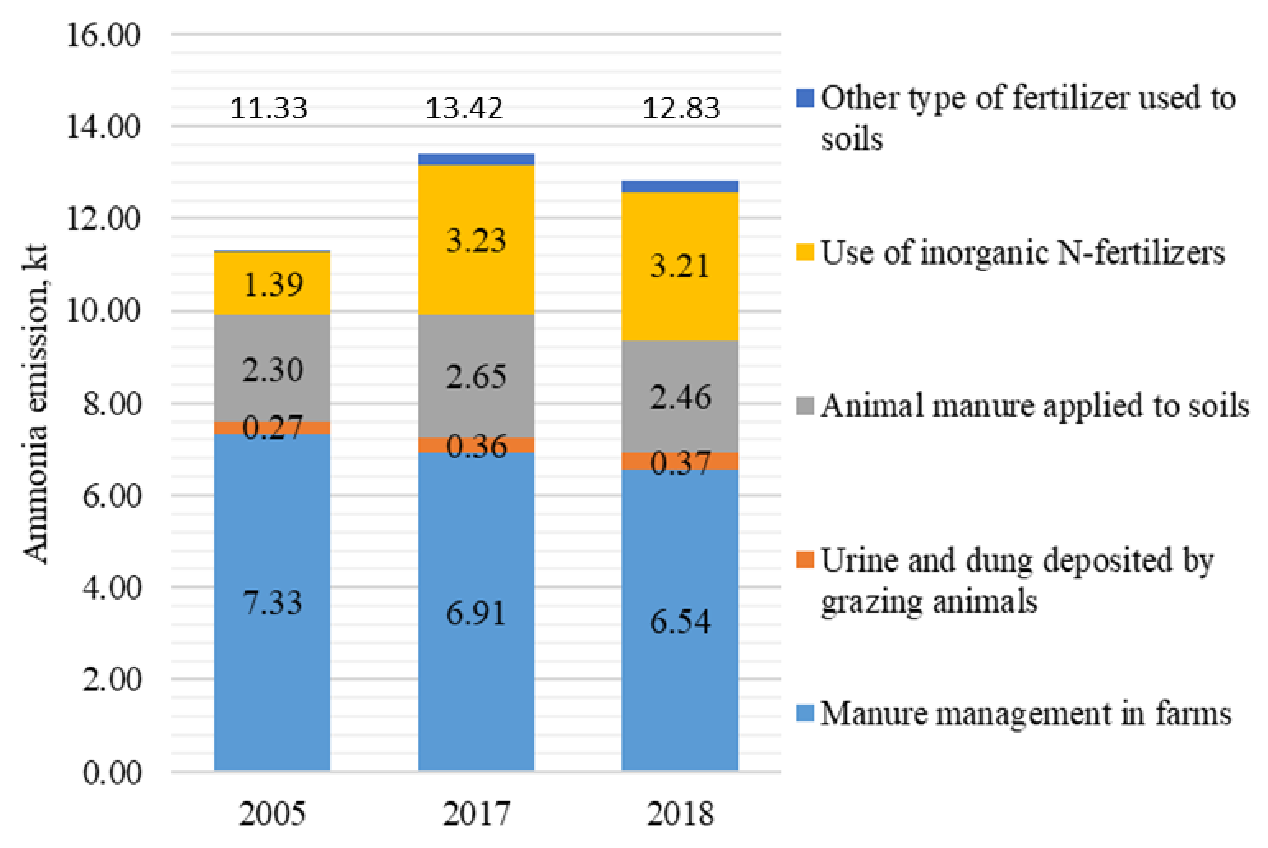

Fig. 2. Quantities of $\mathbf{N H}_{3}$ emissions in agriculture and their sources in 2005, 2017 and 2018 in Latvia

There is legislation in force to regulate pollution from livestock farming. It states that all slurry storages have to be closed or with an artificial floating layer, if the natural crust is not formed [6]. There are still ways to reduce $\mathrm{NH}_{3}$ emissions from storage of manure: covering the storages with higher efficiency covers (reduction higher than $40 \%$ ); covering solid manure stores; the slurry storages constructed after the $1^{\text {st }}$ January 2022 should be low emission storage systems (reduction rate above $60 \%$ to the reference) [7].

The highest increase of $\mathrm{NH}_{3}$ is from use of inorganic fertilizers (57\% comparing 2018 to 2005). It is due to the increased value of nitrogen $(\mathrm{N})$ input to the soil. There were drops of use of inorganic fertilizes in 1995 to $11.5 \mathrm{kt} \mathrm{N}$ from $131.4 \mathrm{kt} \mathrm{N}$ in 1990. Since 1995, there was increase of $\mathrm{N}$ use in form of inorganic fertilizers and in 2005 it was $40.9 \mathrm{kt} \mathrm{N}$, but in $201874.5 \mathrm{kt} \mathrm{N}$ [3], that is increase of $45 \%$ due to the attempt to achieve higher yields. In 2018 there is decrease of about $4 \%$ of the use of inorganic fertilizers and $1 \%$ of $\mathrm{NH}_{3}$ emission. There is a positive trend of the total area certified for organic farming [8] that could contribute for decrease in using inorganic fertilizers.

Emissions from urine and dung deposited by grazing have increased by $27 \%$, because the numbers of non - dairy cattle have been increased from 2005 due to development of beef cattle farming [8]. The previous studies also have showed that there is a change in manure management systems. The share of slurry increases every year due to increased industrial livestock holdings. In 2017, the share of slurry reached $32 \%$ from total manure in Latvia and in some cases $\mathrm{NH}_{3}$ emissions can increase two times, if no reduction measurements are taken in account $[9 ; 10]$.

Figure 3 shows that the highest emissions originate from dairy cattle farming. This tendency has not changed since 2005 (about $58 \%$ ). In 2005, the second largest $\mathrm{NH}_{3}$ emission source is pig rearing $19 \%$, but by 2018 its share has been decreased to $11 \%$. Non - dairy livestock was responsible for $11 \%$ of total agricultural emissions in 2018 and was the $2^{\text {nd }}$ highest $\mathrm{NH}_{3}$ emissions source from manure management. The share of $\mathrm{NH}_{3}$ emissions from farming of laying hens has not changed greatly (6.15\% and $6.78 \%$ in 2005 and 2018, respectively). There is increase of $\mathrm{NH}_{3}$ emissions from rearing of broilers about two times (from $2 \%$ in 2005 to $4 \%$ in 2018). The previously described livestock groups together make the major $\mathrm{NH}_{3}$ emission source with the highest possible reduction response potential, if abatement measures are implemented. 
(a)

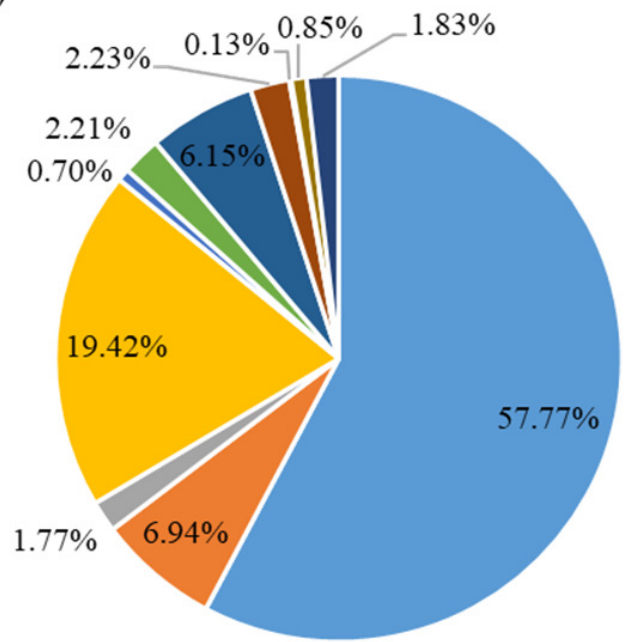

(b)

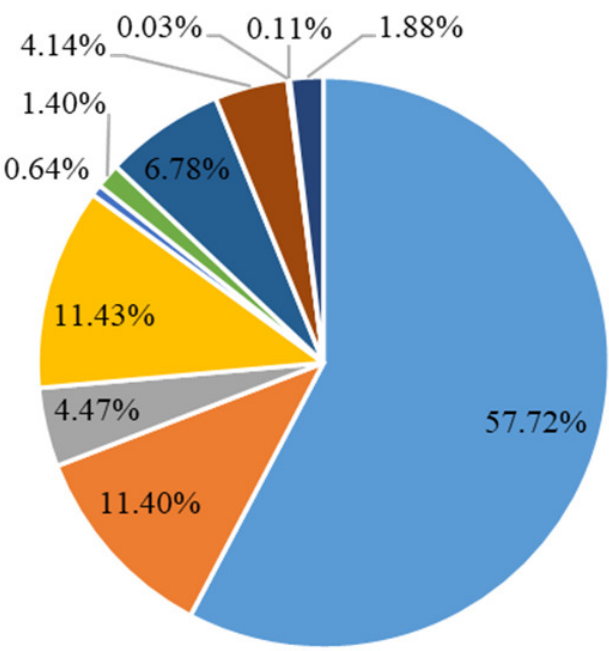

Fig. 3. NH3 emissions from whole manure management cycle by livestock group in Latvia in 2005 (a) and 2018 (b)

Analysing the trends, we can conclude that changes of $\mathrm{NH}_{3}$ emissions are linked to fluctuation of activity data, for example, the number of livestock. It is possible to minimize the dependence on decrease of the livestock number by implementing $\mathrm{NH}_{3}$ emissions abatement strategies to meet the reduction target. There are available a lot of options to reduce the environmental impact of manure management [11], depending on the conditions in the farm and investments, but to account for it, the methodological approach of $\mathrm{NH}_{3}$ emission calculation should be upgraded and the statistical data about manure management need to be more sufficient.

\section{Conclusions}

1. $\mathrm{NH}_{3}$ emissions from Latvian agriculture have increased by $12 \%$ between 2005 and 2018 , but there is $5 \%$ drop of emissions in 2018 comparing to 2017, but we cannot say that it will continue in 2019. Therefore, analysing the trend of the whole study period, there is a possibility that the national target of $1 \%$ reduction of $\mathrm{NH}_{3}$ emissions from 2005 to 2020 will not be reached.

2. During the 2005-2018 period, the largest increase in $\mathrm{NH}_{3}$ emissions was due to the use of inorganic fertilisers by $57 \%$, but there has been a reduction in $\mathrm{NH}_{3}$ emissions of around $6 \%$ in the whole manure management system cycle (housing, storage deposition by grazing and manure application to the soil).

3. In 2018, manure management accounted for $73 \%$ of the total $\mathrm{NH}_{3}$ emissions from the agricultural sector. That is why there is the greatest potential for reducing $\mathrm{NH}_{3}$ emissions.

4. Higher calculation methodological approach needs to be developed for national $\mathrm{NH}_{3}$ emission estimation based on detailed statistical data that would include a wider set of $\mathrm{NH}_{3}$ abatement techniques used in Latvia.

\section{References}

[1] Pan Y., Tian S., Liu D., etc. Source Apportionment of Aerosol Ammonium in an Ammonia-Rich Atmosphere: An Isotopic Study of Summer Clean and Hazy Days in Urban Beijing. Journal of Geophysical Research: Atmospheres, vol. 123(10), 2018, pp. 5681-5689.

[2] Ministru kabineta noteikumi Nr. 614 "Kopējo gaisu piesārņojošo vielu emisiju samazināšanas un uzskaites noteikumi" (Regulations No. 614 of the Cabinet of Ministers "Rules for the reduction and accounting of emissions of total air pollutants"). (In Latvian). [online] [09.03.2020]. Available at: https://likumi.lv.

[3] Latvia's Informative Inventory Report 1990 - 2018 Submitted under the Convention on Long Range Transboundary Air Pollution. Annex I. [online] [17.03.2020] Available at: https://cdr.eionet.europa.eu/lv/un/clrtap/inventories/envxmt3xg/ 
[4] European Environmental Agency European Union emission inventory report 1990-2017 under the UNECE Convention on Long-range Transboundary Air Pollution (LRTAP). Luxembourg: Publications Office of the European Union, 2019. 143 p.

[5] Agriculture, Forestry and Fishery database. [online] [18.03.2020] Available at: http://data.csb.gov.lv/pxweb/en/lauks/?rxid = a79839fe-11ba-4ecd-8cc3-4035692c5fc

[6] National regulations No 829 Regarding Special Requirements for the Performance of Polluting Activities in Animal Housing. [online] [09.03.2020]. Available at: https://likumi.lv/ta/id/271374ipasas-prasibas-piesarnojoso-darbibu-veiksanai-dzivnieku-novietnes

[7] Directive (EU) 2016/2284 of the European Parliament and of the Council of 14 December 2016 on the reduction of national emissions of certain atmospheric pollutants, amending Directive 2003/35/EC and repealing Directive 2001/81/EC. Official Journal of the European Union, L 344, 2016, pp. 1-31.

[8] Latvijas Lauksaimniecība (Agriculture of Latvia). Ministry of Agriculture Republic of Latvia, 2019. 182 p. (In Latvian). [online] [28.03.2020] Available at: https://www.zm.gov.lv/lauksaimnieciba/statiskas-lapas/lauksaimniecibas-gadazinojumi?nid = 531\#jump

[9] Priekulis J., Aboltins A., Laurs A., Melece L. Farm manure amount calculation using statistical data in Latvia./ Agronomy Research, vol. 16 (4), 2018, pp. 1830.-1836.

[10] Frolova O., Priekulis J., Berzina L., etc. Ammonia emission evaluation from manure management. Proceedings of the 16th International Scientific Conference Engineering for Rural Development, vol. 16, May 24-26, 2017, Jelgava, Latvia, pp.1257.-1262.

[11] Bittman S., Dedina M., Howard C.M., etc. Options for Ammonia Mitigation: Guidance from the UNECE Task Force on Reactive Nitrogen, Centre for Ecology and Hydrology, Edinburgh, UK, 2014, 83 p. 